\title{
Policing English PBL teaching mode under the information technology
}

\section{environment}

\author{
Zhe Sun \\ Language Department, Xinjiang Police College, Xinjiang Urumchi, 830011, China
}

\begin{abstract}
Keywords: police English, information technology environment, PBL teaching mode
\end{abstract}
\begin{abstract}
In this paper, based on the English teaching reform of police public security universities and colleges, with the support of information technology, the traditional advantage of PBL teaching mode at the same time, effectively makes up the defect of the PBL teaching mode, enrich the students' learning resources and learning ways, through the establishment of network platform for students and students, students and teachers, students and experts created a convenient communication platform, to break the students received in aspects such as data collection, discussion and evaluation of limitations, teachers, students, teaching materials and teaching methods together in one of the most effective way.
\end{abstract}

\section{Introduction}

As police colleges public required course, English police in public security colleges and universities personnel training curriculum system occupies an important position. Police English aims to cultivate the students' English language application ability, concerning foreign affairs police law enforcement ability and the level of foreign security services, so as to meet the demand of public security actual combat. However, at present most of the public security colleges and universities police English courses due to materials lagging teaching content to keep pace with times development, and the actual work, single teaching means backward, the overall effect is not high.

In the era of information technology development, innovation of traditional sonic policing English teaching mode, to reconstruct the new policing English teaching pattern to adapt to the era development is imperative. With the development of modern education technology and its application in the teaching of the education popularization, based on the problems of learning and information technology, to the public security colleges and universities police English teaching reform has brought the new opportunity, under the new situation and environment, how to make full use of the advantages of information technology, the PBL teaching mode combined with information technology, effectively applied to police English teaching, cultivating students' ability and promote the development of students' high level thinking is the key to this article research.

A police English, information technology environment to carry out the advantage of PBL

PBL teaching model based on the constructivism since the mid - 1960 - s by the American professor of neurology at the Barrows is raised, as to the traditional teacher-centered teaching mode innovation, it advocates the teaching process is given priority to with students, let students take the initiative to find problems, by looking up information, interaction and mutual cooperation with other students, and teachers' guidance, the answer to the problem. In this process, fully exercise the students' thinking ability, practical ability, expression ability, and ability to use knowledge. Since the mid - 90 - s after the PBL teaching mode into medical education in our country, have achieved 
good teaching effect, then many scholars and experts in our country the application of PBL teaching mode in the field of education system and in-depth research. Research and practice show that the wide application of PBL teaching mode makes the learning process for the thoughtful, informative and interesting, more adaptable to the requirement of times development and personnel training mode.

However, any kind of teaching mode is not everything. There's MasterCard \& in the process of PBL teaching mode of practice, there are some limitations: the quantity and quality of teaching resources are limited, the collection of the library and classroom materials co., LTD., the network search coverage also can not meet the requirements; Interactive object is limited to students in the classmate, classroom discussion of limited time and space; Traditional result quantitative student learning way already can't satisfy the PBL teaching mode, students in the learning process of communication ability, cooperation ability and the ability to solve the problem is difficult to use a test paper to show it. With the advent of the era of "Internet +", through the network platform, implementing big data sharing is no longer distant. Through the construction of the network platform, makes up the defect of the PBL teaching mode, make the traditional PBL teaching mode coruscate gives new vitality. The flow of information on the Internet, allowing students to obtain a variety of learning resources, to break the limit of time and space; Students can through the network platform to experts and teachers for help of freedom and equality, between the classmate can real-time and non-real-time communication; Students can make use of network platform for autonomous learning, find information, after class and students communicate with each other, save the time of PBL teaching mode; Using Internet platform to establish a complete and efficient evaluation mechanism, using the Internet software to record the whole learning process of students, objective evaluation of the students' performance, at the same time, the evaluation not only confined to the teacher to the student, can also include students, between students' parents, make the evaluation more diversified and objectivity.

Policing English is a combination of theory and practice unified curriculum, based on policing work content, pay attention to the students of police English skill and the cultivation of the ability of handling cases involving foreign elements, the design concept of PBL teaching mode and police English teaching purpose is completely consistent, with the support of information technology, to the greatest degree of policing English teaching effect optimization. Traditional policing English teaching with textbooks and teachers as the center, the lack of language environment and the real scene, make it easier for language learning in a vacuum. Use of network platform simulation scenario teaching, close to the practical work of police, lets the student in the language situation in what they have learned to express knowledge, not only improve the students' language skills, also makes students understand and familiar with knowledge of police. Most into the police college students' English level is uneven, study result is diamond distribution, PBL teaching mode emphasizes the collaboration among students, in the process of learning, team cooperation, strong or weak is tie-in, complement each other, brainstorming, students complete the teaching mission through cooperation and exchanges, can not only arouse the enthusiasm of students learning, and cultivate the students spirit of solidarity and collaboration, which is the emphasis of police work team consciousness. Therefore, under the information technology support to carry out the PBL teaching mode is an effective way of English teaching reform of police.

under the information environment, police English PBL teaching design. Teaching design "generally includes four basic elements: the learner, objectives, strategies and evaluation" (WuMeiNa, 1994). Emphasis is given priority to with "learning" of the PBL teaching mode, under the information technology rely on, can be design from three aspects: the design of the learning 
objectives (including learners, teachers, learning subjects and the teaching goal), the design of the learning environment, it is the key to the whole teaching design. The last is the design of the learning evaluation and monitoring.

\section{The design of the learning objectives}

The criterion of teaching goals is to organize the teaching activities. The first is for the knowledge structure, cognitive level of learning objects and learning needs analysis, understand the teacher's knowledge structure and the information literacy, the school existing teaching resources and exploitable resources. Through the questionnaire survey to understand the students' learning strategies, learning interest and learning environment, truly reflect the characteristics of PBL teaching mode is given priority to with "learning", through the test, questionnaire and actual practice for students have mastered and in the process of learning tasks should master the knowledge and skills to understand and analysis, and the traditional teaching way is different, the PBL teaching mode based on information technology of the information technology application ability of students, the ability to collect and process information and scientific research ability has certain requirements. Through questionnaire and practical form of the operation, the student to the common operating system software commonly used database language, word processing software, and software, programming languages, presentation software, and information retrieval technology. In addition, the students' scientific research ability as well as the guarantee for smooth finish the task, through the questionnaire survey to understand students familiar with the research method of degree, such as literature method, interview method, experimental method, observation method, questionnaire survey and so on. Teachers' teaching ability analysis, packageLevels of knowledge and innovation ability, research ability and information literacy for effective to carry out the PBL teaching mode play a decisive role, teachers only on the basis of fully understanding and research topics, to provide guidance to students. School is the analysis of the existing resources is also a guarantee of PBL smoothly, category in related aspects of the collection of libraries, and teaching materials to provide what information to students, how to ensure that students get the information through the network platform, these are the factors to consider.

In the process of the analysis of the teaching goal, to distinguish the students to master the content of the "must" and the only need to "understand" the content, to achieve the target, around the "must" to grasp the content of meaning construction. Learning theme design to meet the needs of students, close to the content of the police actual combat, combined with the local characteristics, the development has the characteristics of the local public security subject research. Teachers before the start of the learning task, to do full preparation of the subject matter, will involve many disciplines and professional content, predict students will meet problem, the design of the theme of teacher's language skills and professional knowledge of public security considerations, therefore, the teacher can go to a line of research, get more fresh, life case, combined with the teaching material content, choose the theme of learning goals, let the students with interest to complete the study task.

With the change of science and technology changes with each passing day, based on the teaching aim of PBL teaching model not only for students to master knowledge and language skills requirement, will also put the students' ability to solve this problem, thinking, information literacy, including the information collection and analysis, the use of technology to the vivid expression of views), such as collaborative communication ability as the key. 


\section{About Author}

Zhe Sun (1980-), female, Xinjiang Urumqi, lecturer of Language Department of Xinjiang Police College, master of English language and literature, mainly engaged in the study of English Language Teaching.

\section{Reference}

[1] Leslie p. stern, chief editor, such as, gawain Xu Binyan, cheng korah et al. The constructivism in education [M]. Shanghai: east China normal university press, 2002

[2] David h. Johnson, chief editor, too, zheng you-qun ren, gawain review. The theoretical foundation of the learning environment [M]. Shanghai: east China normal university press, 2002

[3] zhi-ting zhu. Modern education technology, into the information-based education [M]. Beijing: higher education press, 2001

[4] Su Jing. Theory of the status quo and development of college English teaching of police way [J]. Journal of education culture. 2009. (2)

[5] stone belle. Theory of public security professional characteristics of foreign language teaching [J]. Journal of vocational technology, 2006. (4) : 54 